\title{
DISTRIBUTION AND BIOACCUMULATION OF ENDOCRINE DISRUPTING CHEMICALS (EDCS) IN LAGOS LAGOON WATER, SEDIMENT AND FISH
}

\author{
Adeyi, A. A. \\ Department of Chemistry, University of Ibadan, Ibadan, Oyo State, Nigeria \\ Basel Convention Coordinating Centre for Training and Technology Transfer for Africa Region, University of Ibadan, \\ Ibadan, Oyo State, Nigeria \\ Author's e-mail address: bolaoketola@yahoo.com; Telephone No.: +2348037763961 \\ (Received: $3^{\text {rd }}$ April, 2019 Accepted: $3^{\text {rd }}$ May, 2020)
}

\section{ABSTRACT}

\begin{abstract}
Toxic chemical contaminants released from industrial, agricultural, and municipal sources continues to threaten aquatic ecosystems. Aquatic ecosystems act as the final sinks accumulating and transporting numerous chemicals such as octylphenol (OP), nonylphenol (NP) and bisphenol-A (BPA). These chemicals are undesirable as they have been reported to possess endocrine disrupting properties. This study therefore assesses the distribution and bioaccumulation of endocrine disrupting chemicals (EDCs) in Lagos Lagoon. Water and sediment samples were collected at nine different locations on the lagoon. Five different species of fishes were also collected, identified and homogenized prior to sample pre-treatment. Samples were extracted, clean-up, derivatized and analysed by gas chromatography-mass spectrometry. Physicochemical properties of the samples were also determined. In the water samples, BPA was not detected in all the samples collected at the different locations while the concentrations of NP and OP ranged from ND-102 ng/L and ND-127 ng/L, respectively. The concentrations of the targeted compounds in the sediment samples ranged from ND- 5.08 $\mu \mathrm{g} / \mathrm{g}$ BPA, ND-1.90 $\mu \mathrm{g} / \mathrm{g}$ NP, and ND- $2.51 \mu \mathrm{g} / \mathrm{g}$ OP while the concentrations ranged from ND-1139 $\mathrm{ng} / \mathrm{g}$ BPA, ND-476 ng/g NP, and ND-643 ng/g OP in the fish samples. This study revealed the occurrence of EDCs in Lagos lagoon water and their accumulation in biota therein, which can have detrimental effects on other organisms across the food chain. Thus, the need to monitor these endocrine disrupting chemicals is imperative.
\end{abstract}

Keywords: EDCs; BPA; OP; NP; Lagos lagoon

\section{INTRODUCTION}

The concentrations and types of different manmade xenobiotic pollutants continues to be on the increase in aquatic environment (Lecomte et al., 2017). Some of these pollutants are reported to be present in the tissues of aquatic organisms including fish, wildlife and humans (Ali et al., 2019; ESA, 2004). Recently, wide varieties of chemicals, some of which are emerging contaminants, were reported of capable of disrupting the endocrine system of higher life forms by mimicking the hormones (Lauretta, 2019). These substances are unregulated or not completely regulated even in the most developed countries of the world (Esplugas et al., 2007) and can be a hazard to the surroundings and humans. Endocrine disrupting chemicals (EDCs) are a large and varied group of chemicals that are able to cause endocrinemediated abnormalities in invertebrates, fish, avian, reptilian and mammalian including humans (Giulivo et al., 2016; Ferraz et al., 2007). These category of chemicals can be synthetic or naturally occurring and may be directly or indirectly released into the aquatic environment (Vilela et al., 2018; Norman, 2017; Petrie et al., 2017). They are classified as heavy metals and organic chemicals such as polychlorinated biphenyls (PCBs), organochlorine pesticides, plasticizers, surfactants, pharmaceuticals, natural and synthetic estrogens as well as phyto- and myco-estrogens (Burkhardt-Holm, 2010; La Farré et al., 2008).

Some of the reported wildlife and human health effects of these chemicals include dermal toxicity, immunotoxicity, carcinogenicity, neurobehavioural abnormalities, altered or reduced sexual behaviour, attention deficit/hyperactivity disorder, altered thyroid and adrenal cortical function, pathological changes to the spleen, and damaged digestive systems amongst others (Sweeney et al., 2016; Gallo et al., 2016; Sheikh et al., 2016; Dmitruk et al., 2008; Vogel, 2004). The EDCs mimic or antagonize the action of endogenous hormones, interfere with the synthesis, metabolism, transport and excretion of natural hormones; and also alter the hormone 
receptor levels, causing adverse effects (Sheikh et al., 2017; Baker, 2001; EC, 1999). The sources of exposure to EDCs are diverse and vary widely with the main sources in aquatic environment include industrial, agricultural, and municipal sources such as sewage, effluent and agricultural chemicals from runoff (Grieshaber et al., 2018; Carmalin and Lima, 2018; Scholz and Mayer, 2008; Barnhoorn et al., 2004). EDCs present a potential threat to aquatic organisms even at low concentrations of $0.1-10 \mathrm{ng} \mathrm{L^{-1 }}$ and tend to accumulate more in fish than in the water (Luo et al., 2018; Mills and Chichester, 2005). They can affect the health of humans through exposure via the food chain (Diao et al., 2017).

Alkylphenols do not accumulate in water due to their high lipophilicity. Instead, they accumulate in sewage sludge, sediment and bioaccumulate in aquatic biota (Ahel et al., 1994a; 1994b). Bisphenol-A (BPA), also known as 4,4'-dihydroxy2,2-diphenylpropane is a synthetic, organic, and high volume industrial chemical widely used in the production of polycarbonates used for the manufacture of food storage containers, epoxy resins, thermal papers, personal care products and toys (Park et al. 2018; Lim et al., 2018; Liao et al., 2012; Oca et al., 2013; Hormann et al. 2014; Ballesteros-Go'mez et al. 2007; Bhatnagar and Anastopoulos 2007; Gao et al., 2012). Recent animal studies revealed that exposure to BPA led to obesity, thyroid dysfunction, and cardiovascular diseases (Shankar et al. 2012; Desai et al. 2018; Teppala et al. 2012; Han and Hong, 2016; Wang et al., 2015). Exposure to BPA has been associated with type 2 diabetes, leptin levels in pregnant mice and their offspring, and interfered with the lipid and glucose homeostasis in female mice adolescent offsprings (Meng et al., 2018; Schug et al., 2012). Fetal reproductive system development in humans has been linked to maternal exposure to BPA (Miao et al., 2011). It has also been reported that BPA has adverse effects on male reproductive function (Karnam et al., 2015; Sweeney et al., 2015; Manfo et al., 2014) and have the capacity to bind with DNA after metabolic activation with estrogenic activity even at low concentrations (Marwick, 1999). BPA may also directly interfere with the mechanics of cell division and exposure to it may result in various diseases including carcinogenesis (George et al.,
2008; Suarez et al., 2000) and exposure to higher concentrations of BPA in children of ages 3,5 and 7 increased development of asthma in the later years (Xie et al., 2016).

Nonylphenol (NP) is a degradation product of nonylphenol polyethoxylates (NPEOs), which is the most widely produced alkylphenol polyethoxylates (APEOs) (Acir and Guenther, 2018; Abafe et al., 2017). NP is a raw material for making detergents, pesticides, anti-oxidants in plastics and rubbers, as a supplemental agent/stabilizer of polyvinyl chloride (PVC); in the production of lubricants, resins, chemical stabilizers, and antioxidants (Tanghe et al., 2001; Kuramitz et al., 2002; Federal Register, 1990). Due to their common usage in cleaning products and as industrial processing aids, NP and NPE can enter the aquatic environments via industrial and municipal wastewater treatment and discharge (Priac et al., 2017; Morales et al., 2009). The high production volume and common usage of NP and NPE (Talmage, 1994), the degradation of NPE to release more persistent NP (Giger et al., 1984), the uncertainty of NP's persistence in receiving water and sediment, and the documented toxicity of NP to aquatic organisms (Brooke, 1993), established NP as a compound of potential risk to aquatic ecosystems. Abnormal levels of NP result in feminization and masculinization of fish, the imposex phenomenon in female neogastropod mollusks, abnormal growth in several sponges, and delayed development of D-shaped larvae in the Pacific oyster (Crassostrea gigas) (Hill et al., 2002). It has been shown to stay in biologically active state for a longer period of time in the body than that of natural estrogen (Montgomery-Brown and Reinhard, 2003). The estrogenic activity of nonylphenol is three times higher than that of DDT and causes deformities and reproductive problems in wildlife (Sharma and Fekete, 2005; Blackburn et al., 1999; Isobe et al., 2001).

Octylphenol (OP) was found to have more estrogenic character than NP and is used mainly to make phenolic resins (98\%), with the remainder converted into ethoxylates to produce surfactants (Jobbing and Sumpter, 1993; White et al., 1994; $\mathrm{EA}, 2005)$. It can also be present as an impurity in NP along with other OP isomers. Exposure to OP 
has been shown to reduce the size of testes and accessory sex organs, disrupt sperm production, increase the incidence of sperm deformities and alter circulating hormone levels in rats (Boockfor et al., 1997, Herath et al., 2004, Kim et al., 2004, Sharpe et al., 1995). Experiments with human breast cancer cell lines have shown that OP and NP bind to oestrogen receptors and can increase cell proliferation (Blom et al., 1998; Soto et al., 1991; White et al., 1994). The release of organic chemicals into the environment (through industrial and domestic effluents) may accumulate in sediments which act as a sink for many persistent chemicals and may form a source of exposure to aquatic organisms (Houtman et al., 2004).

Lagos lagoon is a major lagoon system in Nigeria which plays various important ecological roles. Several studies have shown that the Lagoon is continuously under the effect of pollution from industries in and around the city of Lagos (Ajao, 1991, 1996; Ajao and Fagade, 1990; Okoye, 1989). The pollution impact in Lagos Lagoon showed that sources of pollution include domestic sewage (faeces), wood shavings (sawdust), sand and gravel extraction, dredging activities, hydrocarbons (waste oil discharge, shipping losses in harbour etc), industrial wastewaters (complex mixture), thermal pollution (cooling system outfall at Ijede, and Egbin (Ajao et al., 1990; Okoye et al., 2010) amongst others. Generally, information on the levels of EDCs in water, sediment and biota (fish) of Lagos lagoon is scarce and to the best of my knowledge, there is no study on the occurrence, distribution and levels of alkylphenols such as nonylphenol, octylphenol and bisphenol-A in water, sediment and fish samples of the lagoon. Thus, this study investigates the distribution, occurrence and levels of nonylphenol, octylphenol and bisphenol-A in Lagos lagoon. Physicochemical characteristics were also determined in the sediment and water samples as well as proximate analysis such as moisture, ash and protein contents etc., of the fish samples.

\section{MATERIALS AND METHODS}

\section{Description of the study area}

Lagos lagoon is located in the south western part of Nigeria. The lagoon empties into the Atlantic through Lagos Harbour, a main channel which is $0.5 \mathrm{~km}$ to $1 \mathrm{~km}$ wide and $10 \mathrm{~km}$ long. The principal ocean port of Lagos is located at Apapa in a broad western branch off the main channel of the harbour. Another branch off the main channel, narrower and longer, separates Lagos Island from Victoria Island, the broad sand spit which forms the coastline (Okusipe, 2008). The lagoon is more than $50 \mathrm{~km}$ long and 3 to $13 \mathrm{~km}$ wide, separated from the Atlantic Ocean by long sand spit 2 to 5 $\mathrm{km}$ wide, which has swampy margins on the lagoon side. Its surface area is approximately $6,354.7 \mathrm{~km}^{2}$. The lagoon is fairly shallow and is not plied by ocean-going ships, but by smaller barges and boats. Lagos city spreads along more than 30 $\mathrm{km}$ of the lagoon's south-western and western shoreline. Pollution by urban and industrial waste is a major problem as large amount of wastewater is released into the lagoon daily. The 11-km-long Third Mainland Bridge was built off the western shore to by-pass congested mainland suburbs. To its north-east the lagoon is connected by a channel passing south of the town of Epe to the Lekki Lagoon. Narrow winding channels connect the system through a broad band of coastal swamps and rivers, as far away as Sapele in Delta State which is $250 \mathrm{~km}$ to the east. Map of Lagos showing the sampling points on the lagoon is shown in Figure 1. 


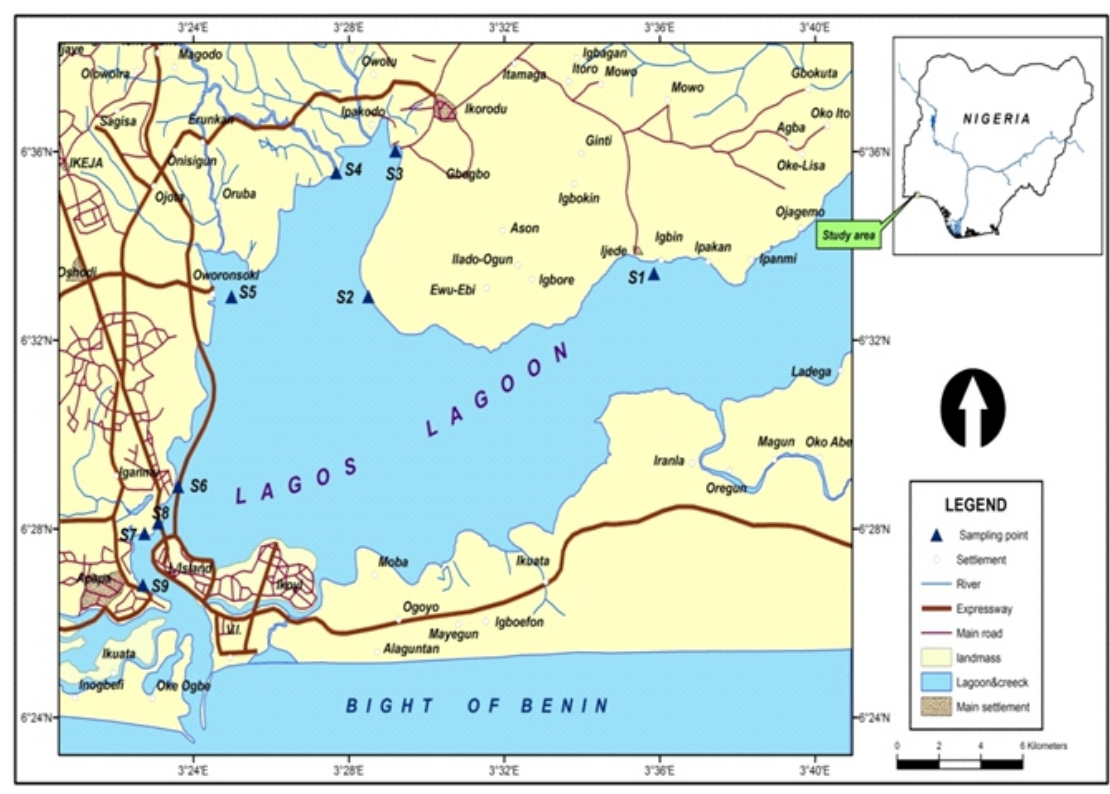

Figure 1: Map of Lagos showing the sampling points on the lagoon

\section{Chemicals and Standards}

All chemicals and reagents used were of analytical grade and of high purity $(99.99 \%)$. Organic solvents, HPLC grade acetone, methanol, dichloromethane, and n-hexane were obtained from Merck (Darmstadt,Germany); anhydrous sodium sulphate and silica gel were obtained from BDH Laboratories (UK). Calibration standards of BPA, nonylphenol, octylphenol and internal standards (bisphenol-A d16 and 4-nnonylphenol) were obtained from Sigma-Aldrich (St Louis, MO).

\section{Sample collection, preservation and pre- treatment}

Nine sampling points were selected on the lagoon (Figure 1). Global Positioning System (GPS) was used to mark the sampling points. Table 1 shows the coordinates of the sampling locations. Composite Water and sediment samples were collected at each sampling point. Water samples were collected into pre-cleaned glass bottles.
Concentrated hydrochloric acid was added to the water sample to prevent microbial degradation of the target compounds (octylphenol (OP), nonylphenol (NP), and Bisphenol-A (BPA)). The water samples were then stored in a refrigerator in the laboratory prior to analysis. The surface sediment samples were collected with a stainless steel van veen grab. Sediment samples collected were kept in a pre-baked aluminium foil and stored at 4 degrees Celsius prior to analysis. Available fish representative samples of different species were collected within the lagoon. Fishing net was used for the catching and fishing boat was used to migrate from the fishing area to the shore. The collected fish samples were martyred and wrapped with prepared aluminium foil (cured in the oven to remove traces of contaminants) and stored in an ice box and transported to the laboratory, where they were stored in the freezer until analysis. Fish samples were identified at the Department of Zoology, University of Ibadan, Ibadan. Nigeria. 
Table 1: GPS coordinates of sampling points on the lagoon

\begin{tabular}{|c|c|c|}
\hline $\begin{array}{l}\text { Sampling } \\
\text { Locations }\end{array}$ & Coordinates & $\begin{array}{c}\text { Anthropogenic activity around the } \\
\text { sampling location }\end{array}$ \\
\hline Egbin & $\begin{array}{l}\text { N 6०33'24.889”' } \\
\text { E 335'51.295”' }\end{array}$ & Functional thermal power station. \\
\hline Ibeshe & $\begin{array}{l}\text { N 632'55.499"' } \\
\text { E 328'30.306”' }\end{array}$ & Textile mill \\
\hline Ikorodu & $\begin{array}{l}\text { N 636’1.013"' } \\
\text { E 329'12.003”' }\end{array}$ & $\begin{array}{l}\text { Container port and a busy jetty for inland } \\
\text { water way transportation. }\end{array}$ \\
\hline Agboyin & $\begin{array}{l}\text { N 632'55.295”' } \\
\text { E 324'58.911'” }\end{array}$ & $\begin{array}{l}\text { Solid waste dumpsite which receive } \\
\text { wastes from Ikeja industrial scheme. }\end{array}$ \\
\hline Oko-baba & 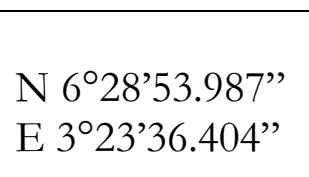 & $\begin{array}{l}\text { Timber merchants using wood } \\
\text { preservatives; sawmill activities and } \\
\text { domestic activities going on. }\end{array}$ \\
\hline Iddo & $\begin{array}{l}\text { N 628'7.703'" } \\
\text { E } 3^{\circ} 23^{\prime} 5.602^{\prime \prime}\end{array}$ & $\begin{array}{l}\text { Cement merchants, washing of cement } \\
\text { bags }\end{array}$ \\
\hline Ijora & 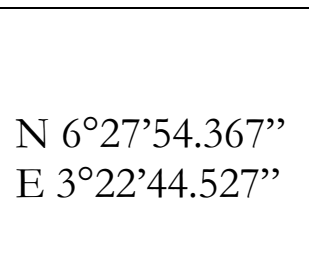 & $\begin{array}{l}\text { Power Holding Company of Nigeria } \\
\text { (PHCN) sub-station which contains } \\
\text { abandoned electrical instruments and } \\
\text { appliances, transformers, cables and } \\
\text { insulators. }\end{array}$ \\
\hline Apapa & $\begin{array}{l}\text { N 626’48.586 } \\
\text { E 3 }^{\circ} 22^{\prime} 42.004^{\prime \prime}\end{array}$ & Nigerian Port Authority \\
\hline Majidun & $\begin{array}{l}\text { N 6०35’33.388”' } \\
\text { E 32 } 7^{\circ} 40.501^{\prime \prime}\end{array}$ & Vegetation cover \\
\hline
\end{tabular}

\section{Sample Extraction and Clean-up}

The water samples were extracted using liquidliquid extraction. Glass fibers filters (whatman GF/F) were used for sample filtration and $100 \mu \mathrm{L}$ each of $1 \mathrm{mg} / \mathrm{L}$ of BPA d16 and 4-n- NP were added as internal standards. $100 \mathrm{~mL}$ samples were extracted using dichloromethane and hexane (1:1 $\mathrm{v} / \mathrm{v})$. To enhance the isolation of the analytes, 10 $\mathrm{mL}$ methanol was also added. Sediment samples were first ground and homogenized using a mortar and pestle. About $5 \mathrm{~g}$ of air-dried and homogenized sediment samples were weighed into a centrifuge tube, spiked with the solution of internal standards $(100 \mu \mathrm{L}$ each of $1 \mathrm{mg} / \mathrm{L} 4-\mathrm{n}$ $\mathrm{NP}$ and BPA-d16) and $25 \mathrm{~mL}$ of a mixture of dichloromethane and hexane $(2: 1 \mathrm{v} / \mathrm{v})$ was added. The tube was then sonicated for $15 \mathrm{~min}$ and then centrifuged at $1500 \mathrm{rpm}$ for $5 \mathrm{~min}$. The extraction was repeated with the same quantity of the solvent mixture. The extracts were combined and concentrated to about $2 \mathrm{~mL}$. Clean-up of the extracts was achieved with a conditioned column chromatography loaded with activated silica gel (mesh size 100/200), glass wool and anhydrous 
sodium sulphate. $2 \mathrm{~mL}$ each of the extracts were added to the top of the column and eluted with 10 $\mathrm{mL}$ of a mixture of dichloromethane and hexane $(2: 1 \mathrm{v} / \mathrm{v})$. Extracts were concentrated using stream of nitrogen gas. The purified extracts were then re-constituted in $2 \mathrm{~mL}$ hexane. About $10 \mathrm{~g}$ of dried and homogenized fish samples were weighed into a thimble, spiked with solution of internal standards $(100 \mu \mathrm{L}$ each of $1 \mathrm{mg} / \mathrm{L} 4-n-$ NP and BPA-d16) then placed in a soxhlet extractor and $25 \mathrm{~mL}$ of a mixture of dichloromethane and hexane $(2: 1 \mathrm{v} / \mathrm{v})$ was added. The extraction was repeated twice with $10 \mathrm{~mL}$ of the solvent mixture. The extracts were combined, concentrated to about $2 \mathrm{~mL}$ and dried over anhydrous sodium sulphate (United States Environmental Protection Agency USEPA method 3540C). Clean-up of the extracts was achieved using column chromatography.

\section{Derivatisation}

Due to the low volatility of targeted compounds, derivatisation was essential to enhance the suitability of the analytes for detection by gas chromatography-mass spectrometry (Goodson $e t$ al., 2002; Oketola and Fagbemigun, 2013). The purified extracts were derivatised by reacting with acetic anhydride as reported elsewhere (Oketola and Fagbemigun, 2013).

\section{Instrumental analysis}

The purified and derivatised extracts were analysed for the targeted compounds (BPA, OP and NP) using a gas chromatograph equipped with a mass spectrometer detector. Separation of the targeted compounds was achieved by injecting about $1.0 \mu \mathrm{L}$ of the extracts into the Shimadzu GCMS-QP2010 system (in a splitless mode) using a HP5-MS capillary column ( $30 \mathrm{~m}$ length, $0.25 \mathrm{~mm}$ internal diameter, $0.25 \mu \mathrm{m}$ film thickness). The operating condition was: injector temperature, $250^{\circ} \mathrm{C}$; detector temperature, $250^{\circ} \mathrm{C}$; oven temperature was initially at $50^{\circ} \mathrm{C}(1 \mathrm{~min})$ and increased to $200^{\circ} \mathrm{C}$ at $10^{\circ} \mathrm{C} / \mathrm{min}(2 \mathrm{~min}$ hold $)$ and to $280^{\circ} \mathrm{C}$ at $20^{\circ} \mathrm{C} / \mathrm{min}$ ( $3 \mathrm{~min}$ hold) to give the total run time of 25 minutes. The carrier gas was helium and flow rate was $1.2 \mathrm{~mL} / \mathrm{min}$. Acquisition MS mode was Selected Ion Monitoring (SIM) mode, ion source temperature was $200^{\circ} \mathrm{C}$ and interface temperature was $250^{\circ} \mathrm{C}$. Accurate quantification of the analytes was performed by first analysing the standard solutions of the analytes at different concentrations level. Detection of each analyte was achieved from the identification of their retention time. The peak height/peak area and the relative abundance as depicted in the mass spectra were used to estimate the concentrations of the analytes. A 5-point relative response factor (RRF) calibration curve was established for the analytes of interest prior to the analysis of the samples. The validation method employed includes the evaluation of the linearity, limits of detection and quantification. Blank determination was also carried out. Linearity of the instrument response was ascertained by analysing series of standard solutions at varying concentrations. Limit of detection (LOD) and limit of quantitation (LOQ) were calculated based on the standard deviation of the response and slope of the calibration curve (Oketola and Fagbemigun, 2013). The linearity, $\mathrm{r}^{2}$ value of the calibration curve for the standards of the targeted compounds was 0.9971, 0.9993 and 0.9880 respectively for 4-octylphenol, 4-nonylphenol and bisphenol-A. Recovery was $95 \%$ and $128 \%$ for nonylphenol and octylphenol, respectively but the recovery of BPA was difficult due to coelution with the internal standard (BPAd16).

\section{Sample Physico-chemical Characteristics}

Water physico-chemical properties such as colour/appearance, $\mathrm{pH}$, odour, temperature, conductivity, total solids, total dissolved solids, total suspended solids, and turbidity were determined using standard procedures (APHA, 2000). Sediment $\mathrm{pH}$, total organic carbon (TOC) (Walkey and Black, 1934), and particle size distribution (ASTM D422, 2007) were determined using standard methods. Proximate analysis such as moisture content, ash content, fat content and protein content were determined in the fish samples using standard method of Association of Official Analytical Chemists.

\section{Statistical Analysis}

Descriptive statistics such as mean and standard deviation were determined using the Statistical Package for the Social Sciences (SPSS) software. 


\section{RESULTS}

\section{Levels of water physico-chemical parameters} and EDCs

The results of water physico-chemical parameters are presented in Table 2. Water temperature, salinity, TDS and EC ranged from $31.0-33.3^{\circ} \mathrm{C}$, 6.1-11.2 $\mathrm{mg} / \mathrm{L}, 5.5-17.4 \mathrm{mg} / \mathrm{L}$, and $4.1-20.0$ $\mu \mathrm{S} / \mathrm{cm}$, respectively while the ambient temperature ranged from $29-32^{\circ} \mathrm{C}$. The mean values of water temperature, salinity, TDS, and EC were $32.1 \pm 0.9^{\circ} \mathrm{C}, \quad 8.50 \pm 1.4 \mathrm{mg} / \mathrm{L}, \quad 9.90 \pm 4.1$ $\mathrm{mg} / \mathrm{L}$, and $16.5 \pm 11 \mu \mathrm{S} / \mathrm{cm}$ respectively. The ambient temperature was lower than the water temperature at all the sampling locations. The highest water temperature was obtained at Egbin, Ikorodu, Majidun, and Ibeshe. This might be caused by the different anthropogenic activities at these locations. The highest water temperature, $33.3^{\circ} \mathrm{C}$, obtained at Egbin might be attributed to the functional thermal power station located at this location while the lowest was obtained at Iddo, Oko-baba and Ijora sampling points (Table 2). The average temperature value obtained in this study was $<40^{\circ} \mathrm{C}$, which depict temperature range that is supportive of good surface water quality (NIS, 2007) and hence convenient enough for the persistence of the targeted organic compounds. Water temperature obtained was comparable with previous studies reported in some selected rivers in the south-western Nigeria (Akoteyon et al., 2011; Osibanjo et al., 2011; Adeogun et al., 2012; Oketola et al., 2006, 2013). The amount of solids present in a water body can be used to estimate the pollution load as a result of both organic and inorganic contaminants present. Total Dissolved Solids (TDS) comprise inorganic salts (principally calcium, magnesium, potassium, sodium, bicarbonates, chlorides and sulphates) and small amounts of organic matter that are dissolved in the water. The average level of TDS in the water sample was $9.90 \pm 4.1 \mathrm{mg} / \mathrm{L}$. Low TDS makes the water more corrosive and can leach metals. It can also restrict the growth of many aquatic organisms and may results in death. The average level of EC in the water was $16.5 \pm 11 \mu \mathrm{S} / \mathrm{cm}$, which was below the levels found in most streams and freshwater system $(150-500 \mu \mathrm{S} / \mathrm{cm})$ to support diverse aquatic life while seawater has an $\mathrm{EC}$ of $5 \mathrm{~S} / \mathrm{m}(5,000,000 \mu \mathrm{S} / \mathrm{m})$ (Behar, 1997). The low conductivity obtained in this study might be attributed to the presence of high levels of organic compounds such as oil, which do not conduct electrical current. Different anthropogenic activities going on at the different sampling locations on the lagoon might also contributed to the high levels of oil and other organic compounds, which ultimately lowers the levels of electrical conductivity of the water.

The results of BPA, NP and OP in the water samples collected at nine different locations on the Lagos lagoon are presented in Table 2. BPA was not detected in all the water samples collected while the concentrations of NP and OP ranged from ND-102 $\mathrm{ng} / \mathrm{L}$ and ND-127 $\mathrm{ng} / \mathrm{L}$, respectively. Ibeshe sampling location that received textile effluent had the highest concentration of OP (127 ng/L) while Agboyi with solid waste dumpsite had the highest concentration of NP (102 ng/L). The NP and OP were both detected in Agboyi and Apapa. NP and OP were detected at varying concentrations at Apapa, Agboyi and Oko-baba, and Apapa, Agboyi and Ibeshe, respectively with different anthropogenic activities (Table 2). The presence of these endocrine disruptors in water collected at some of the sampling locations on the lagoon may be attributed to the continuous discharge of wastewater from both domestic and industrial activities. NP, a degradation product of the surfactant, nonylphenol polyethoxylates (Ying et al., 2002) have been found in water samples from numerous locations worldwide (Kuck and Ballschmiter, 2001) and were present at varying concentrations in the water samples collected in some of the sampling locations on the lagoon. 
Table 2: Levels of water physico-chemical parameters and EDCs in Lagos Lagoon

\begin{tabular}{|l|l|l|l|l|l|l|l|l|}
\hline $\begin{array}{l}\text { Sampling } \\
\text { Stations }\end{array}$ & $\begin{array}{l}\text { Atm } \\
\text { Temperature } \\
\left({ }^{\circ} \mathbf{C}\right)\end{array}$ & $\begin{array}{l}\text { Water } \\
\text { Temp }\left({ }^{\circ} \mathbf{C}\right)\end{array}$ & $\begin{array}{l}\text { Salinity } \\
(\mathbf{m g} / \mathbf{L})\end{array}$ & $\begin{array}{l}\text { TDS } \\
(\mathbf{m g} / \mathbf{L})\end{array}$ & $\mathbf{E C}(\boldsymbol{\mu S} / \mathbf{c m})$ & $\begin{array}{l}\text { BPA } \\
(\mathbf{n g} / \mathbf{L})\end{array}$ & $\begin{array}{l}\text { OP } \\
(\mathbf{n g} / \mathbf{L})\end{array}$ & $\begin{array}{l}\text { NP } \\
(\mathbf{n g} / \mathbf{L})\end{array}$ \\
\hline Egbin & 32.0 & 33.3 & 7.7 & 5.5 & 10.9 & ND & ND & ND \\
\hline Ijora & 31.0 & 31.0 & 8.5 & 6.6 & 10.0 & ND & ND & ND \\
\hline Agboyi & 30.0 & 31.7 & 8.4 & 5.8 & 11.7 & ND & 125 & 102 \\
\hline Ikorodu & 32.0 & 33.1 & 8.7 & 12.2 & 17.6 & ND & ND & ND \\
\hline Majidun & 30.1 & 32.8 & 8.7 & 17.4 & 12.2 & ND & ND & ND \\
\hline Ibeshe & 30.0 & 32.0 & 6.1 & 5.7 & 10.7 & ND & 127 & ND \\
\hline Apapa & 30.0 & 31.5 & 11.2 & 17.3 & 4.1 & ND & 125 & 95.1 \\
\hline Iddo & 29.0 & 31.0 & 7.8 & 9.7 & 20.0 & ND & ND & ND \\
\hline Oko-baba & 29.5 & 31.0 & 6.7 & 8.9 & 18.5 & ND & ND & 95.4 \\
\hline $\begin{array}{l}\text { Mean } \pm \\
\text { SD }\end{array}$ & $30.5 \pm 1.21$ & $32.1 \pm 0.9$ & $8.50 \pm 1.4$ & $9.90 \pm 4.1$ & $16.5 \pm 11$ & 00 & $41.9 \pm 63$ & $32.5 \pm 49$ \\
\hline Range & $29.0-32.0$ & $31.0-33.3$ & $6.1-11.2$ & $5.5-17.4$ & $4.1-20.0$ & ND & ND-127 & ND-102 \\
\hline
\end{tabular}

Note: ND: Not Detected

Effluent discharge from the textile industry located close to River Ibeshe may be a major source of OP. Bisphenol-A which is considered a ubiquitous pollutant was not detected in all the water samples. Hence the level of BPA was within the $1.6 \mathrm{ng} / \mathrm{L}$ set by the European Union (EU, 2008).

Levels of EDCs and physico-chemical parameters in Sediment

There were variations in the concentrations of the targeted compounds in the sediment samples across all the sampling locations. The results of the targeted compounds in the sediment samples and the physicochemical parameters are presented in Table 3. The concentrations of the targeted compounds in the sediment samples ranged from ND-5.08 $\mu \mathrm{g} / \mathrm{g}$ BPA, ND-1.90 $\mu \mathrm{g} / \mathrm{g}$ NP, and ND$2.51 \mu \mathrm{g} / \mathrm{g}$ OP. In most cases, the targeted compounds were not detected in the sediment samples across all the sampling locations except at Egbin, Ibeshe, Ikorodu and Oko-baba. Both BPA and OP were detected at Egbin. NP was only detected in the sediment sample collected at Ibeshe, a location that receives effluent sample from a textile industry, while OP was only detected at Egbin, the location of a thermal power generation station. The levels of alkylphenols and bisphenol-A in aquatic environments have been known to be contributed by anthropogenic activities and that alkylphenols tends to associate with sediments in the aquatic environments (Huang et al., 2012). In this study, OP was not detected in most of the samples but was detected in the sediment sample collected at a location that received effluent from a thermal power station. This suggested that the lagoon received polluted effluent from the activities of the thermal power station and other anthropogenic activities around the lagoon. NP was also not detected in most of the sediment samples but was detected in sediment sample collected at a location that received effluent from a textile mill and it's environ. Bisphenol-A has been reported to be released into the environment from bottles, packaging, landfill leakages, paper, plastic, optic media such as digital versatile discs (DVDs), automotive and other transportation equipment (Huang et al., 2012; Yamamoto et al., 2001). This may explain the levels of bisphenol-A obtained in the sediment collected at some of the locations (such as the timber merchants using wood preservatives coupled with other domestic activities; points with a busy jetty for inland waterway transport and a container port and points receiving effluent from a thermal power station). The highest concentration of bisphenolA was found in sediment with the highest percentage of total organic carbon content suggesting that the sediment organic carbon content plays an important role in controlling the level of phenols in the sediments. Mai et al. (2005) however, reported that sediments with high organic carbon content may favour accumulation of alkylphenols. Also, bisphenol-A is discharged into the aquatic environment not only from the migration from bisphenol-A-based products, but also through effluent from wastewater treatment plants, landfill sites and other anthropogenic activities as bisphenol-A is not produced naturally 
(Huang et al., 2012).

The sediment $\mathrm{pH}$, particle size distribution (sand, silt, and clay) and \% total organic carbon (TOC) ranged from $6.94-7.32,23.3-84.2 \%, 1.30-32.2 \%$, $14.5-44.5 \%$, and $0.32-3.95 \%$, respectively with mean values of $7.14 \pm 0.1,61.7 \pm 21 \%, 12.3 \pm 12 \%$, $26.0 \pm 9.8 \%$, and $2.10 \pm 1.1 \%$, respectively. The $\mathrm{pH}$ of the lagoon sediment was slightly basic, which may influence the bioavailability and ecological risk of some contaminants present therein. However, Xiong et al., (2012) reported that $\mathrm{pH}$ was the most desirable predictor of bacteria community structure in alkaline sediments. The sediment particle size is one of the most significant controls of hydrodynamic characteristics and river morphology which is also associated with sediment transport, deposition processes and river ecology (Heitmuller and Hudson, 2009; Henshaw et al., 2013). The lagoon sediment had high sand content $(61.7 \pm 21 \%)$, followed by clay $(26.0 \pm 9.8 \%)$ and silt $(12.3 \pm 12 \%)$. The total organic carbon (matter) play an important role in the behavior of trace elements in sediment. It may have a significant consequence on the bioavalability, movement and toxicity of trace elements and other micropollutants (Baran $e t$ al., 2019).

Table 3: Sediment characteristics and EDCs of Lagos lagoon

\begin{tabular}{|l|l|l|l|l|l|l|l|l|}
\hline \multirow{2}{*}{$\begin{array}{l}\text { Sampling } \\
\text { locations }\end{array}$} & $\mathbf{p H}$ & \multicolumn{3}{|l|}{ Particle size distribution (\%) } & \%TOC & $\begin{array}{l}\text { BPA } \\
(\boldsymbol{\mu g} / \mathbf{g})\end{array}$ & $\begin{array}{l}\text { NP } \\
(\boldsymbol{\mu g} / \mathbf{g})\end{array}$ & $\begin{array}{l}\text { OP } \\
(\boldsymbol{\mu g} / \mathbf{g})\end{array}$ \\
\cline { 3 - 6 } & & Sand & Silt & Clay & & & & \\
\hline Egbin & 7.32 & 76.5 & 4.50 & 19.0 & 1.47 & 4.49 & ND & 2.51 \\
\hline Ibeshe & 7.23 & 33.0 & 28.7 & 38.3 & 1.27 & ND & 1.90 & ND \\
\hline Ikorodu & 7.16 & 79.0 & 3.50 & 17.5 & 1.88 & 4.49 & ND & ND \\
\hline Majidun & 6.95 & 23.3 & 32.2 & 44.5 & 2.29 & ND & ND & ND \\
\hline Agboyin & 7.20 & 59.0 & 16.3 & 24.7 & 3.32 & ND & ND & ND \\
\hline Oko-baba & 7.17 & 58.0 & 13.7 & 28.3 & 3.95 & 5.08 & ND & ND \\
\hline Iddo & 6.94 & 76.5 & 1.80 & 21.7 & 1.55 & ND & ND & ND \\
\hline Ijora & 7.15 & 65.5 & 9.0 & 25.5 & 2.07 & ND & ND & ND \\
\hline Apapa & 7.10 & 84.2 & 1.30 & 14.5 & 0.32 & ND & ND & ND \\
\hline Mean & $7.14 \pm 0.1$ & $61.7 \pm 21$ & $12.3 \pm 12$ & $26.0 \pm 9.8$ & $2.01 \pm 1.1$ & $1.56 \pm 2.3$ & $0.21 \pm 0.6$ & $0.28 \pm 0.8$ \\
\hline Range & $6.94-$ & $23.3-84.2$ & $1.30-$ & $14.5-$ & $0.32-$ & ND- & ND- & ND- \\
& 7.32 & & 32.2 & 44.5 & 3.95 & 5.08 & 1.90 & 2.51 \\
\hline
\end{tabular}

Note: ND $=$ Not detected

\section{Levels of EDCs in Fish}

Fish samples of five (5) different species were collected in the Lagos lagoon and identified at the Department of Zoology, University of Ibadan (Table 4) and their body fresh weights and lengths were also determined as shown in Table 5. The results of the analysis of fish tissue of different species of fish samples collected in Lagos lagoon is presented in Table 6. Proximate composition determined in the fish samples were moisture, ash, fat and protein contents. These were considered to assess the nutritive value of the fishes. Filimanus heptadactyla (Table 4) commonly classified with threadfin hails from the family name Polynemidae are slivery grey pacifrom marine fish found within the tropical and subtopical waters throughout the world (Idodo-Umeh, 2003). They have the tendency to adapt to wide range of changing salinity. They primarily feed on crustaceans and smaller fishes. Mugil cephalus commonly called a flat head mullet from the family of Mugilidae is usually found in the coastal tropical and subtropical water bodies. Its length is typically between $30-75 \mathrm{~cm}$ (12 - 30 inches) and the body weight can be as high as $4.0 \mathrm{~kg}$. Its mobility range in depth is between $0-120$ meters $(0-390 \mathrm{ft})$ and with temperatures between $8-24^{\circ} \mathrm{C}$ and it may be pelagic or moving into currents below dam. Pomadasys auritus from the family Haemulidae commonly called Longhead grunt has several habitats such as the marine, brackish, benthopelogic tropical and it is widely distributed across the western pacific. It is indeed a rare fish species apparently inhabiting deeper waters of the 
continental shelf. Cynoglossus senegalensis hails from the family Cynoglossidae. It is commonly found on sand and mud bottoms of coastal waters. It feeds on molluscs, shrimps, crabs and fish. Crysichthys nigrodigitatus commonly called Bagrid catfish is from the family Claroteidae and is found in freshwater. It is widely distributed across Africa from Senegal to Angola. It feeds on seeds, insects, bivalves and detritus. Larger ones feed on decapods and fish. It is generally of commercial importance as it is used as commercial game fish and in public aquariums (Idodo-Umeh, 2003). The average fresh body weight of the fish species ranged from $0.17-0.33 \mathrm{~kg}$ (Table 5).

From the five species obtained in the Lagoon, the results obtained (Table 6 ) revealed that BPA, an industrial chemical was found in the fish tissues at concentrations which ranged from $<$ ND-1139 $\mathrm{ng} / \mathrm{g}$ (on wet weight basis). Nonylphenol (NP), a degradation product of the surfactant nonylphenol polyethoxylate was also found at concentration which ranged from $<$ ND -476 $\mathrm{ng} / \mathrm{g}$ while octylphenol (OP) ranged from $<\mathrm{ND}-$ $643 \mathrm{ng} / \mathrm{g}$. The results of the fish tissues analysed confirmed the presence of these endocrine disruptive chemicals in the water and/ or sediment. Concentrations of each of these analytes (BPA, NP and OP) in all the fish species showed slight variation in their bioaccumulation as shown in Figure 2. Bisphenol-A was detected in Pomadasys auritus (FC), Cynoglossus senegalensis (FD) and Chrysichthys nigrodigitatus (FE) but not in Filimanus heptadactyla (FA) and Mugil cephalus (FB). Octylphenol was also detected in three species: Filimanus heptadactyla (FA), Cynoglossus senegalensis (FD), and Chrysichthys nigrodigitatus (FE) while NP was only detected in Filimanus heptadactyla (FA) and Cynoglossus senegalensis (FD). However, none of the targeted compounds (BPA, $\mathrm{OP}$ and NP) was obtained in the tissue of Mugil cephalus (FB).

Generally, the fishes had high percentage moisture content, which ranged from $77.7 \pm 0.04$ $81.8 \pm 0.03 \%$ (Table 7). The percentage ash, crude fat, and crude protein ranged from $2.90 \pm 0.01$ $8.90 \pm 0.01 \%, 14.7 \pm 0.02-65.5 \pm 0.02 \%$, and $83.0 \pm 0.1-84.8 \pm 0.1 \%$, respectively. Mugil cephalus had the highest crude fat content $(65.5 \pm 0.02 \%)$ while Pomadasys auritus had the highest \%ash content (8.90 \pm 0.01$)$ and \%crude protein (84.8 \pm 0.1 . Fish fat is high in omega-3 fatty acids, which offer different health benefits including lowering of cholesterol, triglycerides, and blood pressure; prevent blood clots, reduce inflammation and balance the immune system. Fatty fish are also high in calories which can leads to weight gain.

Table 4: Description of fish species collected in Lagos lagoon

\begin{tabular}{lllll}
\hline $\begin{array}{l}\text { Sample } \\
\text { code }\end{array}$ & Scientific name & Family name & Common name & Habitat \\
\hline FA & Filimanus heptadactyla & Polynemidae & Sevenfinger threadfin & Brackish \\
FB & Mugil cephalus & Mugilidae & Flathead Mullet & Brackish \\
FC & Pomadasys auritus & Haemulidae & Longhead grunt & Brackish \\
FD & Cynoglossus senegalensis & Cynoglossidae & Sole fish & Coastal water \\
FE & Crysichthys nigrodigitatus & Claroteidae & Bagrid catfish & Freshwater \\
\hline
\end{tabular}

Table 5: Characteristic feature of the fish species

\begin{tabular}{lccccc}
\hline Scientific name & $\begin{array}{c}\text { Filimanus } \\
\text { beptadactyla }\end{array}$ & $\begin{array}{c}\text { Mugil } \\
\text { cephalus }\end{array}$ & $\begin{array}{c}\text { Pomadasys } \\
\text { auritus }\end{array}$ & $\begin{array}{c}\text { Cynoglossus } \\
\text { senegalensis }\end{array}$ & $\begin{array}{c}\text { Crysichthys } \\
\text { nigrodigitatus }\end{array}$ \\
\hline Sample code & FA & FB & FC & FD & FE \\
\hline $\begin{array}{l}\text { Number of fishes (n) } \\
\begin{array}{l}\text { Average body wet } \\
\text { weight (kg) }\end{array}\end{array}$ & 1 & 2 & 3 & 2 & 2 \\
$\begin{array}{l}\text { Average body Length } \\
(\mathrm{cm})\end{array}$ & 0.31 & 0.33 & 0.17 & 0.25 & 0.28 \\
\hline
\end{tabular}


Table 6: Concentrations of BPA, OP and NP in fish samples collected in Lagos lagoon

\begin{tabular}{ccccc}
\hline Fish species/ Common names & $\begin{array}{c}\text { Sample } \\
\text { Codes }\end{array}$ & $\begin{array}{c}\text { Bisphenol-A } \\
\text { (BPA) } \\
(\mathrm{ng} / \mathrm{g})\end{array}$ & $\begin{array}{c}\text { Octylphenol } \\
\text { (OP) } \\
(\mathrm{ng} / \mathrm{g})\end{array}$ & $\begin{array}{c}\text { Nonylphenol } \\
\text { (NP) } \\
(\mathrm{ng} / \mathrm{g})\end{array}$ \\
\hline $\begin{array}{c}\text { Filimanus heptadactyla } \\
\text { (Sevenfinger threadfin) } \\
\begin{array}{c}\text { Mugil cephalus } \\
\text { (Flathead mullet) }\end{array}\end{array}$ & $\mathrm{FA}$ & $\mathrm{ND}$ & 630 & 476 \\
$\begin{array}{c}\text { Pomadasys auritus } \\
\text { (Longhead grunt) }\end{array}$ & $\mathrm{FB}$ & $\mathrm{ND}$ & $\mathrm{ND}$ & $\mathrm{ND}$ \\
$\begin{array}{c}\text { Cynoglossus senegalensis } \\
\text { (Sole fish) }\end{array}$ & $\mathrm{FD}$ & 1139 & $\mathrm{ND}$ & $\mathrm{ND}$ \\
$\begin{array}{c}\text { Crysichthys nigrodigitatus } \\
\text { (Bagrid catfish) } \\
\text { Range }\end{array}$ & $\mathrm{FE}$ & 1130 & 630 & 476 \\
\hline
\end{tabular}

Note: ND: Not Detected; LOD: Limit of Detection $=0.003 \mathrm{mg} / \mathrm{kg}$; LOQ: Limit of Quantization $=0.03 \mathrm{mg} / \mathrm{kg}$

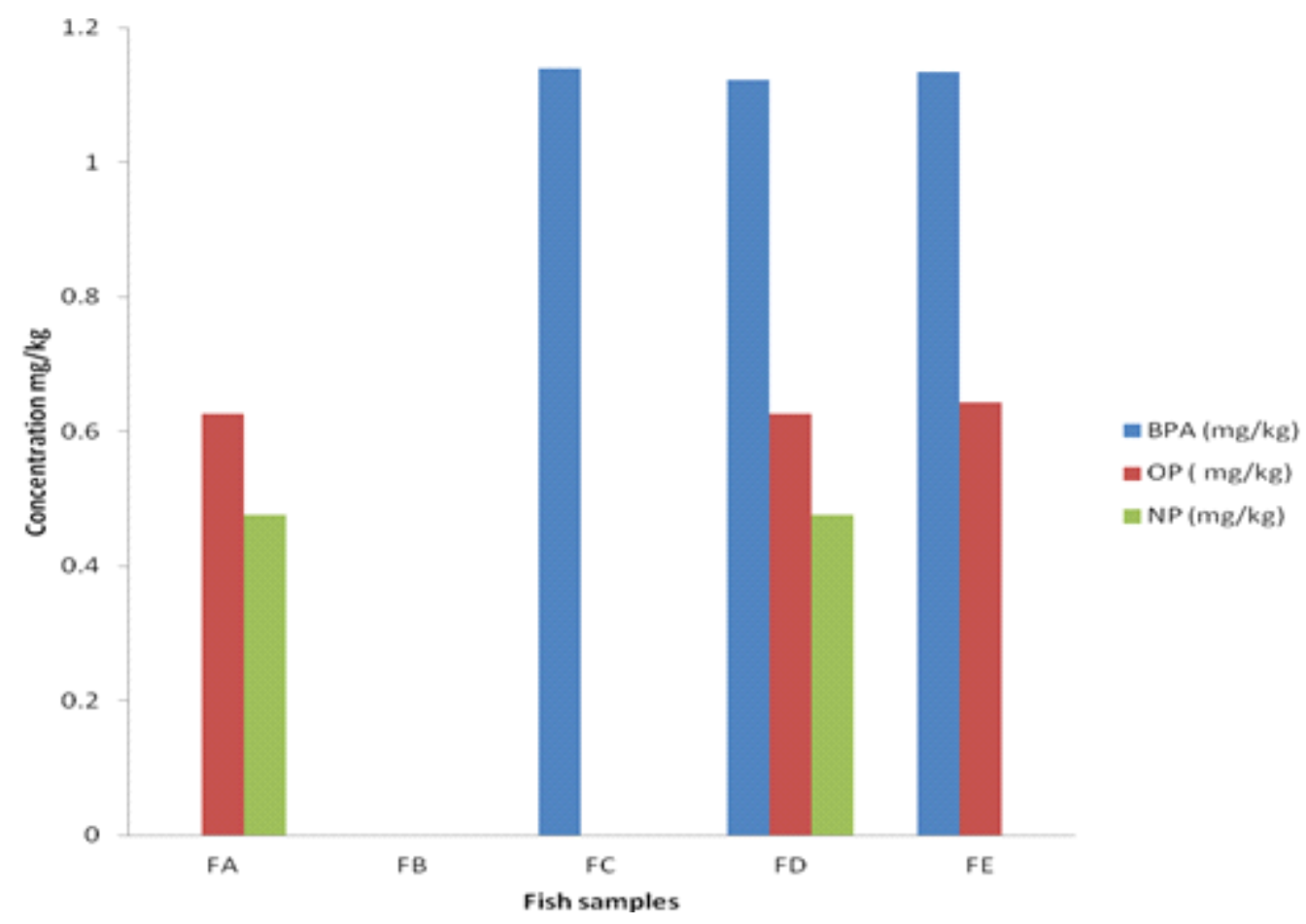

Figure 2: Variation in concentrations of BPA, OP and NP in fish samples collected in Lagos Lagoon 
Table 7: Percentage proximate composition of fish species collected in Lagos lagoon

\begin{tabular}{|c|c|c|c|c|c|}
\hline Fish species & $\begin{array}{l}\text { Sample } \\
\text { Code }\end{array}$ & $\begin{array}{l}\% \text { Moisture } \\
\text { Content }\end{array}$ & $\%$ Ash & $\%$ Crude Fat & $\begin{array}{l}\% \text { Crude } \\
\text { Protein }\end{array}$ \\
\hline $\begin{array}{c}\text { Filimanus } \\
\text { beptadactyla }\end{array}$ & $\mathrm{FA}$ & $77.7 \pm 0.04$ & $3.10 \pm 0.02$ & $15.7 \pm 0.02$ & $83.0 \pm 0.1$ \\
\hline Mugil cephalus & FB & $79.7 \pm 0.04$ & $5.00 \pm 0.02$ & $65.5 \pm 0.02$ & $83.7 \pm 0.1$ \\
\hline $\begin{array}{c}\text { Pomadasys } \\
\text { auritus }\end{array}$ & $\mathrm{FC}$ & $78.9 \pm 0.1$ & $8.90 \pm 0.01$ & $17.9 \pm 0.04$ & $84.8 \pm 0.1$ \\
\hline $\begin{array}{l}\text { Cynoglossus } \\
\text { senegalensis }\end{array}$ & FD & $81.8 \pm 0.03$ & $3.40 \pm 0.00$ & $14.7 \pm 0.02$ & $83.1 \pm 0.1$ \\
\hline $\begin{array}{c}\text { Crysichthys } \\
\text { nigrodigitatus } \\
\text { Range }\end{array}$ & $\mathrm{FE}$ & $79.4 \pm 0.03$ & $2.90 \pm 0.01$ & $16.7 \pm 0.02$ & $84.0 \pm 0.1$ \\
\hline
\end{tabular}

\section{Comparison with other studies}

Studies conducted around the world have confirmed the presence of these phenolic disruptors of hormones in different aquatic habitats. Nonylphenol, octylphenol, bisphenol-A and other related compounds have been detected in rivers, lakes, sea and coastal lagoon. In USA, nonylphenol was detected in fish tissues from
Kalamazoo River, Michigan at concentration levels of $3.3-29.1 \mathrm{ng} / \mathrm{g}$ (Kannan et al., 2003) (Table 8). When compared with the concentrations of the targeted compounds reported in the literature, the concentrations obtained in this study were within the reported concentrations.

Table 8: Endocrine disrupting chemicals accumulated in fish tissues of fishes from rivers, ocean, lagoons and lakes around the world

\begin{tabular}{|c|c|c|c|c|c|c|c|c|}
\hline & Netherland $^{a}$ & Taiwan $^{\mathrm{b}}$ & $\mathrm{USA}^{\mathrm{c}}$ & & China & & Italy & Nigeria \\
\hline EDCs & & & $\begin{array}{c}\text { Kalamazoo } \\
\text { River Michigan }\end{array}$ & $\begin{array}{c}\text { Chongqing } \\
\text { Area }^{\mathrm{d}}\end{array}$ & $\begin{array}{c}\text { Dianchi } \\
\text { Lake }^{\mathrm{e}}\end{array}$ & $\begin{array}{l}\text { Pearl River } \\
\text { Delta }^{\mathrm{f}}\end{array}$ & $\begin{array}{l}\text { Adriatic } \\
\text { Sea }^{g}\end{array}$ & $\begin{array}{c}\text { Lagos Lagoon } \\
\text { (This study) }\end{array}$ \\
\hline 4-NP (ng/g) & - & $22-399.5$ & $3.3-29.1$ & $20-100$ & ND - 18.9 & - & $9.5-1,431$ & $\mathrm{ND}-476$ \\
\hline 4-OP (ng/g) & - & ND - 132.8 & - & - & $\mathrm{ND}-4.6$ & - & $0.3-3.8$ & $\mathrm{ND}-643$ \\
\hline $\mathrm{BPA}(\mathrm{ng} / \mathrm{g})$ & $0.24-2.6$ & & - & - & $\mathrm{ND}-83.5$ & $0.5-2.0$ & - & $\mathrm{ND}-1,139$ \\
\hline
\end{tabular}

Note: ${ }^{a}$ Belfroid et al., 2007; ${ }^{\mathrm{b}} \mathrm{Mao}$ et al., 2007; 'Kannan et al., 2003; 'Shao et al., 2005; Liu et al., 2011; 'Wei et al., 2011; ${ }^{g}$ Ferrara et al., 2005.

\section{CONCLUSION}

This study assessed the occurrence and levels of EDCs such as nonylphenol, octyphenol, and bisphenol-A in water, sediment and fish samples collected in Lagos Lagoon, Nigeria. The study has revealed the occurrence and levels of nonylphenol, octyphenol and bisphenol-A in Lagos lagoon water, sediment and fish. Alkylphenols and bisphenol-A were detected in sediments samples collected from areas of different human activities such as industrial, commercial and domestic activities including the indiscriminate waste disposal. Low concentrations of NP and OP were detected in the water samples while there were no traces of BPA in the water samples collected at different locations on the lagoon. However, the increasing usage of NP and OP in recent years necessitates continued control and monitoring. Although NP and $\mathrm{OP}$ were present at low concentrations, the risks of long-term exposure to these low concentrations remain largely unknown. The study revealed that concentrations of EDCs in Lagos lagoon were generally similar to those that have been reported in the literature. More research needs to be done to determine the potential 
human and environmental health risks posed by exposure to these endocrine disruptors in the aquatic environment and their potential human health risk.

\section{REFERENCES}

Adeogun, A. O., Babatunde, T. A., and Chukwuka, A. V. (2012). Spatial and temporal variations in water and sediment quality of Ona River, Ibadan, Southwest Nigeria. Eur. J. Scient. Res. 74(2): 186-204.

APHA/AWWA/WPCF. (2000). Standard methods for the examination of water and wastewater. 20th ed. Washington, USA: American Public Health Association, American Water Works Association, Water Pollution Control Federation

Ahel, M., Giger, W., and Koch, M. Behaviour of alkylphenol polyethoxylate surfactants in the aquatic environment. 1. Occurrence and transformation in sewage treatment. Water Research 1994a. 28: 1131-1142.

Ahel, M., Giger, W., and Schaffner, C. Behaviour of alkylphenol polyethoxylate surfactant in the aquatic environment. 2. Occurrence and transformation in rivers. Water Research 1994b. 28: 1143-1152.

Ajao, E. A. (1996). Review of the State of Pollution of the Lagos lagoon. NIOMR Tech. Paper No 106.

Ajao, E. A. and Fagade S. O. (1990). A study of sediments and communities in Lagos lagoon. Oil and Chemical Pollution 7:85117.

Ajao, E. A., Okoye, B. C. O., and Adekanmbi, E. O. (1991). Environmental Pollution in Nigerian Coastal Waters. A case study of Lagos lagoon. In Book of Abstracts of accepted papers, $2^{\text {nd }}$ National Environmental Seminar on Water Quality Monitoring and status in Nigeria. 16-18, October, 1991, Kaduna, Nigeria.

Akoteyon, I. S., Omotayo, A. O. Soladoye, O. and Olaoye, H. O. (2011). Determination of water quality index and suitability of urban river for municipal water supply in Lagos-Nigeria. Eur. J. Scient. Res. 54(2):263-271.

ASTM Standard D422, (1963). Standard Test Method for Particle-Size Analysis of Soils. American Society for Testing and
Materials International United State of America: Pennsylvania. 2007.

Baker, V. (2001). Endocrine disrupters - testing strategies to assess human hazard. Toxicology in Vitro. 15:413-419.

Ballesteros-Gómez A, Ruiz FJ, Rubio S, PérezBendito D. (2007). Determination of bisphenols $\mathrm{A}$ and $\mathrm{F}$ and their diglycidyl ethers in wastewater and river water by coacervative extraction and liquid chromatography-fluorimetry. Anal. Chim. Acta. 603(1):51-59.

Baran, A., Mierzwa-Hersztek, M. Gondek, K., Tarnawski, M., Szara, M., Gorczyca, O. and Koniarz, T. (2019). The influence of the quantity and quality of sediment organic matter on the potential mobility and toxicity of trace elements in bottom sediment. Environmental Geochemistry and health. 41, 2893-2910.

Barnhoorn, I. E. J., Bornman, M. S., Pieterssse, G. M., Van-Vuren, J. H. J. Histological evidence of intersex in feral sharptooth catfish (Clarias gariepinus) from an estrogen-polluted water source in Gauteng, South Africa. Environ Toxicol 2004. 19:603-608.

Behar, S. (1996). Testing the waters: chemical and physical vital signs of a river. River Watch Network. ISBN: 0787234923.

Belfroid, A., Van Velzen, M., Van der Horst, B., and Vethaak, D. (2002). Occurrence of bisphenol-A in surface water and uptake in fish: evaluation of field measurements. Chemosphere 49:97-103.

Bhatnagar A, Anastopoulos I. (2007). Adsorptive removal of bisphenol A (BPA) from aqueous solution: A review. Chemosphere. 168:885-902.

Blackburn, M.A., Kirby, S. J., and Waldock, M. J. (1999). Concentrations of alkylphenol polyethoxylates entering UK estuaries. Marine Pollution Bulletin 38:109-118.

Blom, A., Ekman, E., Johannisson, A., Norrgren, L., and Pesonen, M. (1998). Effects of xenoestrogenic environmental pollutants on the proliferation of a human breast cancer cell line (MCF-7). Arch Environ Contam Toxicol.34(3):306-310.

Boockfor, F. R., Blake, C. A. (1997). Chronic administration of 4-tert-octylphenol to 
adult male rats causes shrinkage of the testes and male accessory sex organs, disrupts spermatogenesis, and increases the incidence of sperm deformities. Biol. Reprod. 57(2):267-277.

Brooke, L.T. (1993). Acute and chronic toxicity of nonylphenol to ten species of aquatic organisms. Final Report 68-C1-0034. United States Environmental Protection Agency, Minnesota: Duluth.

Burkhardt-Holm, P., Schwartz, P., Thorpe, K.L., Bucheli, T.D. and Wettstein, F.E. Shortterm exposure to the environmentally relevant estrogenic mycotoxin zearalenone impairs reproduction in fish. The Science of the total environment 2010. 409(2):326-33.

Carmalin, S. A. and Lima, E. C. (2018). Removal of emerging contaminants from the environment by adsorption. Ecotoxicology and Environmental Safety 150:1-17.

CBS News, 2013. BPA exposure may raise child's asthma risk. [Accessed 2018 March 20]:[2 p.]. https://www.cbsnews.com/ news/bpa-exposure-may-raise-childsasthma-risk/

Desai, M., Ferrini, M. G., Han, G., Jellyman, J. K., Ross, M. G. (2018). In vivo maternal and in vitro BPA exposure effects on hypothalamic neurogenesis and appetite regulators. Environ. Res. 164:45-52

Diao, P. P., Chen, Q., Wang, R., Sun, D., Cai, Z. P., Wu, H., et al. (2017). Phenolic endocrinedisrupting compounds in the Pearl River Estuary: Occurrence, bioaccumulation and risk assessment. Science of the Total Environment, 584-585, 1100-1107.

Dmitruk, U., Piascik, M., Taboryska, B., and Dojlido, J. Persistent organic pollutants (POPs) in bottom sediments of the vistula river, Poland. Clean 2008. 36: 222-229.

European Commission (1999). Communication from the Commission to the Council and the European Parliament. Community Strategy for Endocrine Disrupters a range of substances suspected of interfering with the hormone systems of humans and wildlife. COM (1999) 706 final. Brussels.

Environment Agency (EA) (2005). Environmental Risk Evaluation Report:
4-tert-Octylphenol, April 2005. www.environment-agency.gov.uk

European Union (EU) (2008). European Union Updated Risk Assessment Report. Bisphenol A, CAS No: 80-05-7. Institute for Health and Consumer Protection, European Chemicals Bureau, European Commission Joint Research Centre, 3rd Priority List, Luxembourg: Office for Official Publications of the European Communities.

Esplugas, S., Bila, D. M., Krause, L. G. T., and Dezotti, M. (2007). Ozonation and advanced oxidation technologies to remove endocrine disrupting chemicals (EDCs) and pharmaceuticals and personal care products (PPCPs) in water effluents. J. Hazard. Mater. 149:631-642.

Food and Agricultural Organisation (FAO). Ecosystem Issues. OAR/National Undersea Research Programme/ G.Mc Fall. www.fao.org 2002.

Federal Register. (1990). Testing consent order on 4-nonylphenol branched. CAS 84852-153. Fed Reg 1990. 55:5991-5994.

Ferrara, F., Fabietti, F., Delise, M., and Funari, E. (2005). Alkylphenols and Alkylphenol ethoxylates contamination of crustaceans and fishes from the Adriatic Sea (Italy). Chemosphere 59:1145-1150.

Ferraz N., Carnevi-Nande, G., Rossotti M., Miguez M.N., Last, J.A., and GonzalezSapienza, G. (2007). Specific immunoassays for endocrine disruptor monitoring using recombinant antigens cloned by degenerated primer PCR. Analytical and Bioanalytical Chemistry 389:2195-2202.

Gallo, M. V., Ravenscroft, J., Carpenter, D. O., Frye, C., Akwesasne, Cook, B., Schell, L. M., (2016). Endocrine disrupting chemicals and ovulation: is there a relationship? Environ. Res. 151: 410-418.

Gao, Y., Li, Y., Zhang, L., Huang, H., Hu, J., Shah, S.M., Su, X. (2012). Adsorption and removal of tetracycline antibiotics from aqueous solution by graphene oxide. J. Colloid Interface Sci. 368: 540-546.

George, O., Bryant, B. K., Chinnasamy, R., Corona, C., Arterburn, J. B., and Shuster, C. B. (2008). Bisphenol-A directly targets 
tubulin to disrupt spindle organization in embryonic and somatic cells. American Chemical Society Chemical Biology 3(3):167-179.

Giger, W., Brunner P. H., and Schaffner, C. (1984). 4-Nonylphenol in sewage sludge: accumulation of toxic metabolites from nonionic surfactants. Science 225: 623-625.

Giulivo, M., Lopez de Alda, M., Capri, E., Barcelo, D. (2016). Human exposure to endocrine disrupting compounds: their role in reproductive systems, metabolic syndrome and breast cancer. A review. Environ. Res. 151:251-264.

Goodson, A., Summerfield, W. and Cooper, I. (2002). Survey of Bisphenol-A and Bisphenol-F in Canned Foods," Food Additives and Contaminants 19(8):796802.

Grieshaber, C. A., Penland, T. N., Kwak, T. J., Cope, W. G., Heise, R. J., Law, J. M., Shea, D., Aday, D. D., Rice, J. A., and Kullman, S. W. (2018). Relation of contaminants to fish intersex in riverine sport fishes. Science of the Total Environment 643:73-89.

Han, C., and Hong, Y. C. (2016). Bisphenol A, hypertension, and cardiovascular diseases: epidemiological, laboratory, and clinical trial evidence. Curr. Hypertens. Rep. 18:15.

Heitmuller, F. T. and Hudson, P. F. (2009). Downstream trends in sediment size and composition of channel-bed, bar, and bank deposits related to hydrological and lithologic controlsin the Llano River watershed, central Texas, USA. Geomorphology. 112, 246-260.

Henshaw, A. J., Gurnell, A. M., Bertoldi, W. and Drake, N. (2013). An assessment of the degree to which Landsat TM data can support the assessment of fluvial dynamics as revealed by changes in vegetation extent and channel position, along a large river. Geomorphology. 202, 74-85.

Jin, W., Watanabe, G., Arai, K., Suzuki, A. K., and Taya, K. (2002). Adverse effects of environmental toxicants, octylphenol and bisphenol $\mathrm{A}$, on male reproductive functions in pubertal rats. Endocrine 25(2):163-72.

Hill, M., Stabile, C., Steffen, K., and Hill, A. (2002). Toxic effects of endocrine disrupters on freshwater sponges: common developmental abnormalities. Environmental Pollution 117:295-300.

Hormann, A. M., vom Saal, F. S., Nagel, S. C., Stahlhut, R. W., Moyer, C. L., Ellersieck, M. R., Welshons W. V., Toutain, P. L., and Taylor, J. A. (2014). Holding thermal receipt paper and eating food after using hand sanitizer results in high serum bioactive and urine total levels of bisphenol A (BPA). Plos One 9(10):e110509.

Houtman, C. J., Cenijn, P. H., Hamers, T., Lamoree, M. H., Legler, J., Murk, A. J. and Brouwer, A. (2004). Toxicological profiling of sediments using in vitro bioassays, with emphasis on endocrine disruption. Environmental Toxicology and Chemistry 23(1):32-40.

Huang, Y .Q, and Wong, C. K. C., Zheng, J. S., Bouwman, H., Barra R., Wahlström, B., Neretin, L., and Wong, M. H. (2012). Bisphenol A (BPA) in China: A review of sources, environmental levels, and potential human health impacts. Environment International 42:91-99.

Idodo-Umeh, G. (2003). Freshwater fishes of Nigeria (Taxonomy, ecological notes, diets and utilization). Idodo-Umeh Publishers limited Benin City. ISBN 9788052-01-0

Isobe, T., Nishiyama, H., Nakashima, A., and Takada, H. (2001). Distribution and behavior of nonylphenol, octylphenol, and nonylphenol monoethoxylate in Tokyo metropolitan area: their association with aquatic particles and sedimentary distributions. Environmental Science and Technology 35:1041-1049.

Jobbing, S. and Sumpter, J. P. (1993). Detergent components in sewage effluent are weakly estrogenic to fish - An in-vitro study using rainbow-trout (Oncorhynchus mykiss) hepatocytes. Aquatic Toxicology 27(34):361-372.

Kannan, K., Keith, T. L., Naylor, C. G., Staples, C. A., Snyder, S. A., Giesy, J. P. (2003). 
Nonylphenol and nonylphenol ethoxylates in fish, sediment, and water from the Kalamazoo River, Michigan. Archives of Environmental Contamination and Toxicology 44:77-82.

Karnam, S., Ghosh, R., Mondal, S., and Mondal, M. (2015). Evaluation of subacute bisphenol-A toxicity on male reproductive system. Vet. World 8(6):738-744.

Kim, S. K., Lee, H. J., Yang, H., Kim, H. S., and Yoon, Y. D. (2004). Prepubertal exposure to 4-tert-octylphenol induces apoptosis of testicular germ cells in adult rat. Arch Androl., 50(6):427-441.

Kuck, H. M. and Ballschmiter, K. (2001). Determination of Endocrine-Disrupting Phenolic Compounds and Estrogens in Surface and Drinking Water by HRGC(NCI)-MS in the Pictogram Per Litre Range. Environmental Science and Technology 35(15):3201-3206.

Kuramitz. H., Saiotoh, J., Hattori, T., and Tanaka, S. (2002). Electrochemical removal of pnonylphenol from dilute solution using a carbon fiber anode; Wat. Res. 36:33233329.

La Farré, M., Pérez, S., Kantiani, L., and Barcelo, D. (2008). Fate and toxicity of emerging pollutants, their metabolites and transformation products in the aquatic environment. Trends Anal. Chem. 27, 991-1007.

Liao, C., Liu, F., Guo, Y., Moon, H. B., Nakata, H., Wu, Q., and Kannan, K. (2012). Occurrence of eight bisphenol analogues in indoor dust from the United States and several Asian countries: implications for human exposure. Environ. Sci. Technol 46:9138-9145.

Lim, H. J., Lee, E. H., Lee, S. D., Yoon, Y., and Son, A. (2018). Quantitative screening for endocrine-disrupting bisphenol A in consumer and household products using NanoAptamer assay. Chemosphere 211:72-80.

Liu, J., Wang, R., Huang B., Lin, C., Wang, Y., and Pan, X. (2011). Distribution and Bioaccumulation of Steroidal and Phenolic Endocrine Disrupting Chemicals in Wild Fish Species from Dianchi Lake, China. Environmental
Pollution 159(10):2815-2822.

Luo, Z., Lu, J., Li, H., Tu, Y., Wan, Y. and Yang, Z. (2018). Air-assisted liquid-liquid microextraction integrated with QuEChERS for determining endocrinedisrupting compounds in fish by high performance liquid chromatographytandem mass spectrometry. Food Chemistry 260:174-182.

Mai, B. X., Chen, B., Duan, J. C., Luo, X. J., Yang, Q. S., Sheng, G. Y. and Fu, J. M. (2005). Concentrations of alkylphenols in sediments from the Pearl River estuary and South China Sea, South China. Marine Pollution Bulletin 50:993-1018.

Manfo, F. P. T., Jubendradass, R., Nantia, E. A., Moundipa, P. F., and Mathur, P. P. (2014). Adverse effects of bisphenol A on male reproductive function. Rev. Environ. Contam. Toxicol. 228:57-82.

Mao, I. F., Lu, Y. Y., and Chen, M. L. (2007). A simplified method for simultaneous quantitation of alkylphenols and Alkylphenol ethoxylates in meat and fish using high-performance liquid chromatography with fluorescence detection. International Journal of Environmental Analytical Chemistry 86(10):713-722.

Marwick, C. (1999). Hormonally active agents throughout the environment. Journal of the American Medical Association 282:722.

Meng, Z., Wang, D., Yan, S., Li, R., Yan, J., Teng, M., Zhou, Z., and Zhu, W. (2018). Effects of perinatal exposure to BPA and its alternatives (BPS, BPF and BPAF) on hepatic lipid and glucose homeostasis in female mice adolescent offspring. Chemosphere 212:297-306.

Miao, M., Yuan, W., He, Y., Zhou, Z., and Wang, J. (2011). In utero exposure to bisphenol-A and anogenital distance of male offspring. Birth Defects Res. A. Clin. Mol. Teratol. 91(10):867-872.

Mills, L. J., and Chichester, C. (2005). Review of evidence: Are endocrine-disrupting chemicals in the aquatic environment impacting fish populations? Science of the Total Environment 343(1-3):1-34.

Montgomery-Brown, J., and Reinhard, M. (2003). 
Occurrence and Behavior of Alkylphenol Polyethoxylates in the Environment. Environmental Engineering Science 20(5):471-486.

Network of Reference Laboratories (NORMAN) (2017). Research Centres and Related Organisations for Monitoring of Emerging Environmental Substances. (www. norman-network.net).

Nigerian Industrial Standard (NIS) (2007). Nigerian Standard for Drinking Water Quality. NIS 554: 2007, ICS 13.060.20, Approved by the Standard Organization of Nigeria (SON) Governing Council, 2007. pp: 14-18.

Oca, M. L., Ortiz, M. C., Herrero, A., Sarabia, L A. (2013). Optimization of a GC/MS procedure that uses parallel factor analysis for the determination of bisphenols and their diglycidyl ethers after migration from polycarbonate tableware. Talanta 106:266-280.

Oketola, A. A., Osibanjo, O., Ejelonu, B. C., Oladimeji, Y. B., and Damazio, O. A. (2006). Water Quality Assessment of River Ogun Water around the Cattle Market of Isheri, Nigeria. Journal of Applied Science. 6(3):511 - 517.

Oketola, A. A., Adekolurejo, S. M. and Osibanjo, O. (2013). Water Quality of River Ogun using Multivariate Statistical Techniques. Journal of Environmental Protection 4(5):466-478.

Oketola, A. A. and Fagbemigun, T. K. (2013). Determination of Nonylphenol, Octylphenol and Bisphenol-A in Water and Sediments of Two Major Rivers in Lagos, Nigeria. Journal of Environmental Protection 4:38-45.

Okoye, B. C. O. (1989). A study of some heavy metals in Lagos lagoon. Ph.D. Thesis, Department of Chemistry, Obafemi Awolowo University, Ile-Ife, Nigeria. 1989. $142 p$

Okusipe, O. M. (2008). Lagos Lagoon Coastal Profile: Information Database For Planning Theory, Department of Urban and Regional Planning, University of Lagos. 2008.

Osibanjo, O., Daso, A. P., and Gbadebo, A. M.
(2011). The impact of industries on surface water quality of river Ona and river Alaro in Oluyole industrial estate, Ibadan, Nigeria. Afr. J. Biotechnol. 10(4):696-702.

Park, S. A., Park, S. J., Jeong, M. J., Choi, J. C., Kim, M. K. (2018). Fast and simple determination and exposure assessment of bisphenol A, phenol, p-tertbutylphenol, and diphenylcarbonate transferred from polycarbonate foodcontact materials to food simulants. Chemosphere 203:300-306.

Petrie, B., Barden, R., and Kasprzyk-Hordern, B., (2017). A review on emerging contaminants in wastewaters and the environment: current knowledge, understudied areas and recommendations for future monitoring. Water Res. 72, 3-27.

Scholz, S., and Mayer, I. (2008). Molecular biomarkers of endocrine disruption in small model fish. Mol. Cell. Endocrinol. 293:57-70.

Schug, T. T., Barouki, R., Gluckman, P. D., Grandjean, P., Hanson, M., Heindel, J. J. (2012). PPTOX III: Environmental stressors in the development origins of disease-evidence and mechanisms. Toxicol. Sci. 131:343-350.

Shankar, A., Teppala, S., and Sabanayagam, C. (2012). Bisphenol A and peripheral artery disease: Results from NHANES. Environ. Health Perspect. 120:1297-1300.

Sharma, V. K. and Fekete, J. (2005). Inorganic and organic pollutants in the Hungarian environment. 183-193.

Shao, B., Hu, J. Y., Yang, M., An, W., and Tao, S. (2005). Nonylphenol and nonylphenol ethoxylates in river water, drinking water, and fish tissues in the area of Chongqing, China. Archives of Environmental Contamination and Toxicology 48:467473.

Sharpe, R. M., Fisher, J. S., Millar, M. M., Jobbing, S., and Sumpter, J. P. (1995). Gestational and lactational exposure of rats to xenoestrogens results in reduced testicular size and sperm production. Environ Health Perspect. 103(12):1136-1143.

Sheikh, I. A., Turki, R. F., Abuzenadah, A. M., 
Damanhouri, G. A., Beg, M. A., (2016). Endocrine disruption: computational perspectives on human sex hormonebinding globulin and phthalate plasticizers. PLoS One 11 (3), e0151444.

Sheikh, I. A., Tayubi, I. A., Ahmad, E., Ganaie, M. A., Bajouh, O. S., AlBasri, S. F., Abdulkarim, I. M., Beg, M. A. (2017). Computational insights into the molecular interactions of environmental xenoestrogens 4-tert-octylphenol, 4nonylphenol, bisphenol A (BPA), and BPA metabolite, 4-methyl-2, 4-bis (4hydroxyphenyl) pent-1-ene (MBP) with human sex hormone-binding globulin. Ecotoxicol. Environ. Saf. 15:284-291.

Soto, A. M., Justicia, H., Wray, J. W., Sonnenschein, C. P. (1991). Nonylphenol: an estrogenic xenobiotic released from 'modified' polystyrene. Environ Health Perspect. 92:167-173.

Suarez, S., Sueiro, R.A. and Garrido, J. (2000). Genotoxicity of the coating lacquer on food cans, bisphenol A diglycidyl ether (BADGE), its hydrolysis products and a chlorohydrin of BADGE. Mutation Research 470(2):221-228.

Sweeney, M. F., Hasan, N., Soto, A. M., and Sonnenschein, C. (2015). Environmental endocrine disruptors: effects on the human male reproductive system. Rev. Endocr. Metab. Disord. 16(4):341-357.

Sweeney, M. F., Hasan, N., Soto, A. M., and Sonnenschein, C. (2016). Environmental endocrine disruptors: effects on the human male reproductive system. Rev. Endocr. Metab. Disord. 16:341-357.

Talmage, S. S. (1994). Environmental and Human Safety of Major Surfactants- Alcohol Ethoxylates and Alkylphenol Ethoxylates. The Soap and Detergent Association. Florida, Boca Raton: Lewis Publication.

Tanghe, T. and Verstraete, W. (2001). Adsorption of nonylphenol onto granular activated carbon; Water, Air, and Soil Pollution 131:61-72.

Teppala, S., Madhavan, S., and Shankar, A. (2012). Bisphenol A and metabolic syndrome: results from NHANES. Int. J. Endocrinol.
Article ID 598180, 5 pp.

Vilela, C. S. L., Bassin, J. P., and Peixoto, R. S. (2018). Water contamination by endocrine disruptors: Impacts, microbiological aspects and trends for environmental protection. Environmental Pollution 235:546-559

Vogel, J. M. (2004). Tunnel Vision: The regulation of endocrine disruptors. Policy Scienes. 37:277-303.

Walkley, A., Black, I. A. (1934). Methods of soil analysis. Soil Sci. 37:29-38.

Wang, Y., Zhu, J., Huang, H., Cho, H.H. (2015). Carbon nanotube composite membranes for microfiltration of pharmaceuticals and personal care products: capabilities and potential mechanisms. J. Membr. Sci. 479:165-174.

Wei, X., Huang, Y., Wong, M. H., Giesy, J. P., and Wong, C. K. C. (2011). Assessment of risk to humans of bisphenol-A in marine and freshwater fish from Pearl River Delta, China. Chemosphere 85:122-128.

White, R., Jobbing, S., Hoare, S. A., Sumpter, J. P., and Parker M. G. Endocrinology 1994. 135, 175.

Xie, M. Y., Ni, H., Zhao, D. S., Wen, L. Y., Li, K. S., Yang, H. H., Wang, S. S., Zhang, H., and Su, H. (2016). Exposure to bisphenol A and the development of asthma: a systematic review of cohort studies. Reprod. Toxicol. 65:224-229.

Xiong, J., Liu, Y., Lin, X., Zhang, H., Zeng, J., Hou, J., Yang, Y., Yao, T., Knight, R. and Chu, H. (2012). Geographic distance and $\mathrm{pH}$ drive bacterial distribution in alkaline lake sediments across Tibetan Plateau. Environ Microbiol. 14(9):2457-2466.

Yamamoto, T., Yasuhara, A., Shiraishi, H. and Nakasugi, O. (2001). Bisphenol A in hazardous waste landfill leachates. Chemosphere 42:415-418.

Ying, G. G., Williams, B., and Kookana, R. (2002). Environmental Fate of Alkylphenols and Alkylphenol ethoxylates: A Review," Environment International 28(3):215226. 